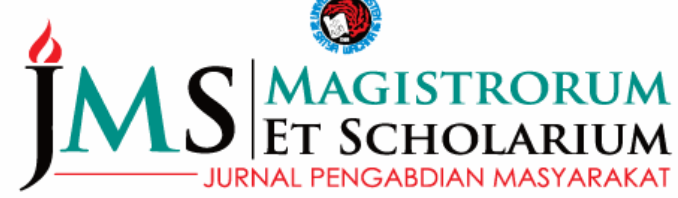

P-ISSN: 2722-9270 ejournal.uksw.edu/jms

\section{Pendampingan Pembuatan Media Budidaya Cacing Sutera pada Kelompok Pembudidaya Ikan di Kota Sorong}

Dwi Indah Widya Yanti*

Enny Romanwati

Roger R. Tabalessy

Melisa Ch. Masengi

Clara N. Payung

Program Studi Manajemen Sumberdaya Perairan Universitas Kristen Papua Sorong

\section{A R T I C L E I N F O}

\section{Article history:}

Received 17-11-2020

Revised 18-11-2020

Accepted 14-12-2020

Key words:

media, silk worm, cultivation

\begin{abstract}
A B S T R A C T
Silk worms are natural food for fish that have high protein content. Silk worms are generally obtained by fish farmers from natural catches because no one has cultivated them, due to the lack of knowledge or skills of fish cultivators. The habit of relying on worms from natural supplies makes the availability of silk worms increasingly difficult on the market. For this reason, it is necessary to increase the ability of fish farmers in cultivating silk worms. The method used in community service activities is to provide counseling as well as practice making hairworm cultivation media. Community service activities carried out in the form of counseling and practice of making media for silk worm cultivation have a positive impact on fish cultivator groups. This is because the cultivator group gets new knowledge and can practice it in their cultivation activities.
\end{abstract}

\begin{abstract}
A B S T R A K
Cacing sutera merupakan pakan alami ikan yang memiliki kandungan protein tinggi. Cacing sutera umumnya diperoleh petani ikan dari hasil tangkapan alam karena belum ada yang membudidayakan, disebabkan kurangnya pengetahuan atau keterampilan pembudidaya ikan. Kebiasaan mengandalkan cacing dari pasokan alam menyebabkan ketersediaan cacing sutera semakin sulit di pasaran. Untuk itu peningkatan kemampuan petani ikan dalam membudidayakan cacing sutera perlu dilakukan. Metode yang dilakukan dalam kegiatan pengabdian pada masyarakat adalah dengan memberikan penyuluhan sekaligus mempraktekkan pembuatan media budidaya cacing rambut.
\end{abstract}

\footnotetext{
*Corresponding author: indahwidyayanti83@gmail.com
} 
Kegiatan pengabdian pada masyarakat yang dilaksanakan dalam bentuk penyuluhan dan praktek pembuatan media untuk budidaya cacing sutera memberikan dampak positif pada kelompok pembudidaya ikan. Hal ini karena kelompok pembudidaya mendapat pengetahuan baru dan bisa mempraktekkannya dalam kegiatan budidaya yang mereka lakukan.

\section{PENDAHULUAN}

Salah satu jenis pakan hidup yang paling disenangi dan mempunyai kandungan nutrisi yang baik bagi larva ikan adalah cacing sutera. Pertumbuhan dan kandungan nutrisi cacing sutera (Tubifex sp.) sangat dipengaruhi oleh media kultur sebagai tempat pemeliharaan cacing sutera. Kandungan $\mathrm{N}$ dan $\mathrm{P}$ di dalam pupuk organik tersebut merupakan nutrient yang dapat dimanfaatkan untuk memacu pertumbuhan dan peningkatan kualitas nutrisi yang terkandung dalam cacing sutera (Tubifex sp) (Hamron et al., 2018). Menurut, Khairuman et al, 2008, kandungan nutrisi cacing sutera tidak kalah dibandingkan dengan pakan ikan alami lainnya seperti Infusoria, Chlamidona, Chloromonas dan Artemia.

Pakan alami cacing sutera yang berada di alam memiliki ketersediaan yang masih relatif sedikit dibandingkan dengan perkembangan akuakultur. Kebutuhan cacing sutera pada tahun 2014 mencapai 1.067.565 liter. Kebutuhan cacing sutera (Tubifex sp.) diperoleh dari penangkapan alam, terutama dari sungai yang memiliki dasar perairan yang berlumpur dengan aliran air yang tenang dan memiliki sumber bahan organik yang tinggi (Masrurotun \& Hutabarat, 2014). Kelangkaan cacing sutera biasa terjadi ketika memasuki musim hujan, jadi ketersediaan cacing sutera masih bersifat musiman, yang semakin lama semakin sulit di dapat.

Cacing sutera umumnya diperoleh petani ikan di Kota Sorong dari hasil tangkapan alam karena belum ada yang membudidayakan, hal ini disebabkan kurangnya pengetahuan atau keterampilan pembudidaya ikan. Sampai sekarang kebisaan mengandalkan cacing dari pasokan alam menyebabkan ketersediaan cacing sutera semakin sulit di pasaran. Harga cacing sutera di pengepul tergolong mahal, yaitu $1 \mathrm{~kg}$ bersih seharga seratus ribu rupiah. Harga yang mahal ini dikarenakan kelangkaan cacing sutera di kota Sorong dan mencarinya di alam tergolong susah, sebagian besar para pengepul mencari di selokan-selokan besar atau drainase pinggir jalan. Di lihat dari segi peluang usaha, harga cacing sutera sangat menggiurkan bagi pedagang/pengepul. Tapi bagi petani ikan atau pembudidaya ikan harga tersebut sangat mahal, mereka lebih memilih mencari sendiri sesuai kebutuhan, tapi adakalanya karena kekurangan mereka membeli dari pengepul. Masalah kelangkaan cacing sutera di alam sebagai pakan alami, diharapkan dapat teratasi dengan melakukan budidaya cacing sutera.

Berdasarkan permasalahan tersebut maka Program Studi Manajemen Fakultas Pertanian melaksanakan kegiatan pengabdian pada masyarakat kepada Kelompok Pembudidaya Ikan. Kegiatan pengabdian pada masyarakat itu sendiri merupakan salah satu Tridarma Perguruan Tinggi sebagai salah satu upaya untuk membekali para kelompok pembudidaya ikan tentang cara pembuatan media untuk budidaya cacing sutera. 


\section{METODE PELAKSANAAN}

Kegiatan pengabdian pada masyarakat dilaksanakan di Kediaman Bapak Suroto, Distrik Sorong Timur Kota Sorong Papua Barat. Kegiatan diikuti oleh 5 kelompok pembudidaya ikan. Metode yang dilakukan dalam kegiatan pengabdian pada masyarakat adalah dengan memberikan penyuluhan sekaligus mempraktekkan pembuatan pakan alami ikan dari cacing rambut.

Alat yang digunakan untuk budidaya cacing sutera media tray atau nampan yaitu: Nampan atau tray, ember untuk mencampur media substrat dan sebagai penampung air dan timbangan digital. Adapun bahan yang digunakan untuk budidaya cacing sutera media tray atau nampan yaiu: Media (substrat) budidaya lumpur organik berpasir, ampas tahu dan kotoran ayam), probiotik; EM-4 dan molase/ larutan gula putih atau merah dengan air hangat. Alat dan bahan tersebut cukup sederhana dan dapat dengan mudah ditemukan oleh petani ikan.

Pembuatan media budidaya cacing sutera sebagai berikut: Media yang digunakan adalah fermentasi kotoran ayam dan fermentasi ampas tahu. Kotoran ayam yang digunakan adalah kotoran ayam yang sudah kering dan dihancurkan sampai halus. Masing-masing bahan yaitu kotoran ayam dan ampas tahu, kemudian dilakukan proses fermentasi dengan dosis $1 \mathrm{ml} \mathrm{EM} 4$ dicampur dengan 200-250 ml air dan $25 \mathrm{ml}$ tetes molase/tetes tebu atau air gula/25 ml air untuk $1 \mathrm{~kg}$ bahan baku, kemudian disimpan selama 5-7 hari. Jika media tidak menimbulkan bau busuk, berarti media siap digunakan.

Volume wadah $30 \times 28 \times 12$ yaitu $10,080 \mathrm{~m}^{3}$. Lumpur yang dimasukkan harus lebih banyak dari media tambahan karena tidak ada lapisan tanah/kompos sebagai bahan tambahan organik, yaitu lumpur $60 \%$ dan media $40 \%$. Volume media yang digunakan 30 x 28x 7 yaitu 5,880 $\mathrm{m}^{3}$. Maka jumlah media yang digunakan $5,88 \mathrm{Kg}$ per wadah.

\section{HASIL DAN PEMBAHASAN}

Kelompok pembudidaya ikan yang mengikuti pelatihan pembuatan pakan budidaya cacing sutera ini umumnya merupakan kelompok budidaya pembenihan ikan, yang terdiri dari pembenihan ikan lele, nila, mas, koi, dan berbagai macam jenis ikan hias. Kelompok pembudidaya ikan ini dibentuk berdasarkan Keputusan Menteri Kelautan dan Perikanan, Nomor: 14 Tahun 2012 tentang Pedoman Umum Penumbuhan dan Pengembangan Kelembagaan Pelaku Utama Perikanan, guna meningkatkan kemampuan pelaku utama perikanan melalui pendekatan kelompok sehingga kelembagaan kelompok pelaku utama dan pelaku usaha kelautan dan perikanan mampu tumbuh dan berkembang lebih baik. Kelompok pembudidaya ikan yang mengikuti kegiatan penyuluhan dapat dilihat pada Tabel 1. 
Tabel 1. Kelompok Pembudidaya

\begin{tabular}{|c|c|c|c|c|c|c|}
\hline \multirow[b]{2}{*}{ No. } & \multirow{2}{*}{$\begin{array}{c}\text { Nama } \\
\text { Kelompok }\end{array}$} & \multicolumn{3}{|c|}{$\begin{array}{c}\text { Jumlah Anggota Kelompok } \\
\text { (Orang) }\end{array}$} & \multirow{2}{*}{$\begin{array}{c}\text { Alamat Sekretariat } \\
\text { Kelompok }\end{array}$} & \multirow{2}{*}{$\begin{array}{c}\text { Jenis Ikan } \\
\text { yang } \\
\text { dibudidayakan }\end{array}$} \\
\hline & & $\begin{array}{l}\text { Jumlah } \\
\text { Laki- } \\
\text { Laki }\end{array}$ & $\begin{array}{c}\text { Jumlah } \\
\text { Perempuan }\end{array}$ & $\begin{array}{c}\text { Total } \\
\text { Jumlah }\end{array}$ & & \\
\hline 1. & BANYUMILI & 7 & 3 & 10 & $\begin{array}{c}\text { Jl. Melati Raya. Rt } 03 \text { Rw } 01 \\
\text { KM, 8,5 Kel.Klasabi Kec. } \\
\text { Sorong Manoi } \\
\end{array}$ & Lele, Nila \\
\hline 2. & ANEKA & 6 & 4 & 10 & $\begin{array}{l}\text { Jl. Ataa Rt } 04 \text { Rw } 11 \text { Kel. } \\
\text { Giwu Kec. Klaurung }\end{array}$ & $\begin{array}{l}\text { Lele, Nila, Ikan } \\
\text { Hias(platty, guppy, } \\
\text { black gosh, } \\
\text { komet,cupang) }\end{array}$ \\
\hline 3. & $\begin{array}{l}\text { LELE } \\
\text { BAROKAH }\end{array}$ & 8 & 2 & 10 & $\begin{array}{c}\text { Jln.Melati Raya, RT 001/RW } \\
\text { 007, Harapan Indah. Kel. } \\
\text { Klawuyuk Kec. Sorong } \\
\text { Timur }\end{array}$ & Lele \\
\hline 4. & $\begin{array}{l}\text { MINA } \\
\text { LESTARI }\end{array}$ & 8 & 3 & 10 & $\begin{array}{l}\text { J1. Dorowati Rt } 03 \text { Rw } 03 \\
\text { Kel. Klasaman Kec. } \\
\text { Klaurung }\end{array}$ & Lele \\
\hline 5. & $\begin{array}{l}\text { MAULIDA } \\
\text { KOI }\end{array}$ & 6 & 4 & 10 & $\begin{array}{l}\text { Jl. Madukoro, NO.46 Rt } 05 \\
\text { Rw } 013 \text { Kel.Klasaman. Kec. } \\
\text { Klaurung }\end{array}$ & KOI \\
\hline
\end{tabular}

Pada umumnya pelaku utama yakni pembudidaya ikan yang tergabung dalam kelompok binaan ini, melakukan kegiatan budidaya sebagai mata pencaharian pokok. Dengan adanya kegiatan pengabdian masyarakat oleh UKiP Sorong yang bekerjasama dengan Dinas Kelautan Perikanan Kota Sorong ini dapat memberikan pengetahuan kepada pembudidaya ikan dalam upaya pembudidayaan cacing sutera sebagai pakan alami ikan. Kegiatan pendampingan dilakukan dengan melakukan pemaparan materi dengan media tertayang dan juga Demonstrasi Cara (Damcar) agar pelaku utama/pembudidaya bisa dengan mudah memahami dan mengimplemetasikannya. Selain itu pendampingan penyuluhan ini berlanjut setiap bulannya, yang dilakukan oleh Penyuluh Kota Sorong guna terus mendampingi kegiatan usaha pelaku utama khususnya pembudidaya ikan sehingga ada keberlanjutan dan peningkatan pengetahuan, keterampilan dan sikap yang dapat meningkatkan produksi kelompok perikanan dan juga meningkatkan kesejahteraan masyarakat perikanan.

Cacing sutera dapat dibudidayakan di kolam tanah, terpal atau plastik, kolam semen,wadah tray atau nampan plastik. Habitat cacing sutera di temukan di daerah tropis, dasar perairan yang disukai cacing ini adalah berlumpur dan mengandung bahan organik, karena bahan-bahan organik yang telah terurai dan mengendap di dasar perairan merupakan makanan utamanya. Media lumpur dalam substrat diperlukan sebagai tempat Tubifex sp. melekatkan ataupun membenamkan kepalanya untuk mencari makan.

Pada kegiatan pengabdian masyarakat ini dilaksanakan praktek pembuatan media tumbuh cacing sutera dengan menggunakan media kotoran ayam 70\%, ampas tahu 30. Media kotoran ayam dan ampas tahu merupakan media yang memiliki 
kandungan nutrisi yang tinggi. Pada pembuatan media untuk budidaya cacing sutera, diperlukan proses fermentasi kotoran ayam. Proses fermentasi diperlukan pada pemupukkan kotoran ayam dengan tujuan untuk memperbaiki kualitas pupuk. Proses fermentasi juga dapat meningkatkan nilai rasio $\mathrm{C} / \mathrm{N}$. Kotoran ayam difermentasi dengan EM-4 yaitu Effective Microorganisms-4 biasa disingkat EM-4. EM-4 adalah suatu kultur campuran beberapa mikroorganisme yang dapat digunakan sebagai inokulan mikroba yang berfungsi sebagai alat pengendali biologis yaitu sebagai penekan dan pengendali perkembangan hama dan penyakit. EM-4 mengandung beberapa mikroorganisme utama yaitu bakteri fotosintetik, bakteri asam laktat, Ragi (yeast), Actinomycetes dan jamur fermentasi (Kusumorini et al., 2017).

Ampas tahu merupakan limbah nutrisi pabrik tahu yang di hasilkan dari sisa pengolahan kedelai menjadi tahu. Ampas tahu merupakan sumber protein tinggi yaitu sebesar $21,91 \%$. Protein dan karbohidrat dibutuhkan oleh cacing sutera karena dapat berpengaruh terhadap pertumbuhan cacing sutera. Berdasarkan hasil proksimat yang dilakukan, ampas tahu mengandung $\mathrm{N}$ sebesar 3,71 \% (Fajri et.al., 2017).

Cacing sutera atau cacing rambut termasuk kedalam kelompok cacing-cacingan (Tubifex sp). Dalam ilmu taksonomi hewan, cacing sutera digolongkan kedalam kelompok Nematoda. Disebut cacing sutera karena cacing ini memiliki tubuh yang lunak dan sangat lembut seperti halnya sutera/rambut. Cacing sutra tergolong ke dalam oligochaeta telah menjadi incaran untuk dibudidayakan karena memiliki kemampuan untuk hidup pada densitas yang tinggi dan memiliki kesanggupan untuk bertahan pada lingkungan dengan kelarutan oksigen yang sangat rendah. Kebutuhan akan cacing sutra sebagai pakan alami sangat diperlukan karena biota ini sangat bernutrisi dengan nilai protein yang tinggi dalam, menunjang pertumbuhan, memperpanjang masa reproduksi dan menstimulasi pemijahan ikan (Febrianti et al., 2020).

Dikarenakan pada fase pembenihan benih ikan sangat memerlukan asupan makanan berupa protein tinggi. Cacing sutera sebagai pakan alami mempunyai beberapa kelebihan yaitu, selain kandungan nutrisinya yang baik, juga memiliki gerakan yang lambat, ukurannya kecil, dan mudah dicerna (Masrurotun \& Hutabarat, 2014). Cacing sutera diminati oleh benih ikan karena sesuai dengan ukuran bukaan mulut benih ikan. Cacing sutera segar yang masih hidup bergerak aktif sehingga nafsu makan benih ikan meningkat, ini membuat benih ikan lebih cepat bertumbuh dan sehat sehingga mortalitas atau tingkat kematiannya bisa diminimalisir.

Budidaya cacing sutera merupakan salah satu alternatif mengatasi kekurangan pakan alami cacing rambut saat musim penghujan. Berdasarkan penelitian, budidaya cacing sutra dapat dilakukan sendiri tanpa mencari lagi diparit dan sungai dengan biaya produksi Rp 46.500 jika dikonversikan menghasilkan 1200 g cacing sutra untuk pemeliharaan 56 hari, tetapi perlu diperhatikan bahwa budidaya cacing sutra sebaiknya dilakukan secara indoor, untuk mengantisipasi hinggapnya larva serangga dari jenis Chironomus sp. (Nuraini et al., 2019). Dokumentasi kegiatan pengabdian pada masyarakat dapat dilihat pada Gambar 1. 

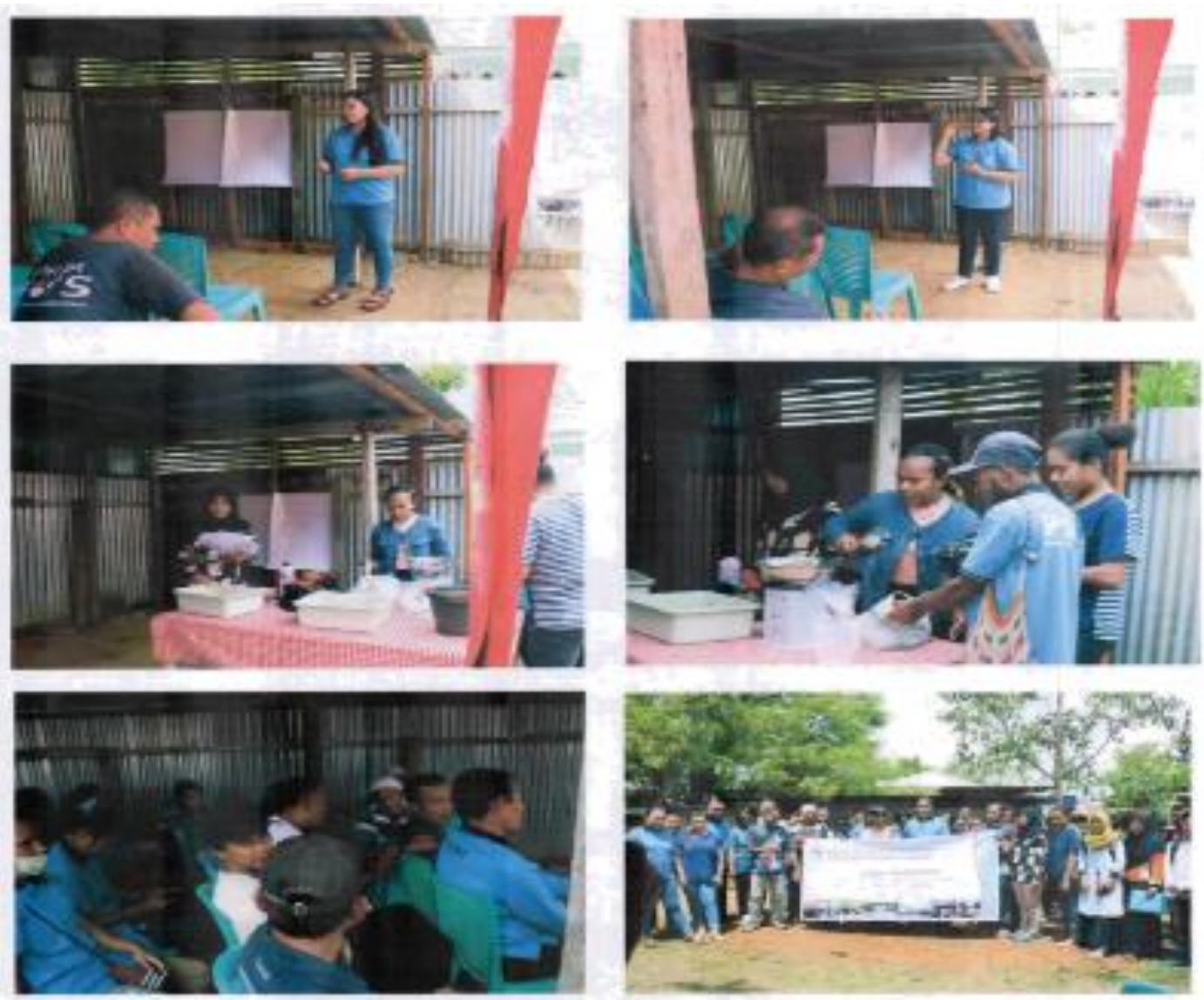

Gambar 1. Dokumentasi Kegiatan Pengabdian Pada Masyarakat.

\section{SIMPULAN}

Kegiatan pengabdian pada masyarakat yang dilaksanakan dalam bentuk penyuluhan dan praktek pembuatan media untuk budidaya cacing sutera memberikan dampak positif pada kelompok pembudidaya ikan. Hal ini karena kelompok pembudidaya mendapat pengetahuan baru dan bisa mempraktekkannya dalam kegiatan budidaya yang mereka lakukan. 


\section{DAFTAR PUSTAKA}

Fajri, W.F, S. dan J. H. (2017). Pengaruh Penambahan Kotoran Ayam, Ampas Tahu Dan Tepung Tapioka Dalam Media Kultur Terhadap Biomassa, Populasi Dan Kandungan Nutrisi Cacing Sutera (Tubifex sp.). Journal of Aquaculture Management and Technology, 4(4), 95-100. ttp://ejournals1.undip.ac.id/index.php/jamt Journal of Aquaculture Management and Technology Online di : http://ejournal-s1.undip.ac.id/index.php/jamt

Febrianti, S., Shafruddin, D., \& Supriyono, E. (2020). Budidaya Cacing Sutra ( Tubifex sp .) dan Budidaya Ikan Lele Menggunakan Sistem Bioflok di Kecamatan Simpenan, Sukabumi ( Silkworm Cultivation ( Tubifex sp .) and Catfish Cultivation Using Biofloc Systems in Simpenan District, Sukabumi ). Jurnal Pusat Inovasi Masyarakat, 2(3), 429-434.

Hamron, N., Johan, Y., \& Brata, B. (2018). Analisis pertumbuhan populasi cacing sutera (Tubifex sp) sebagai sumber pakan alami ikan. Naturalis: Jurnal Penelitian Pengelolaan Sumber Daya Alam Dan Lingkungan, 7(2), 79-90. https://doi.org/10.31186/naturalis.7.2.6026

Khairuman, Khairul Amri, dan Toguan Sihombing. (2008). Peluang Usaha Budidaya Cacing Sutera. Andromeda Pustaka.

Kusumorini Astuti, T. C. dan L. D. U. (2017). Pengaruh Pemberian Fermentasi Kotoran Ayam Terhadap Populasi Dan Biomassa Cacing (Tubifex tubifex). Jurnal Biologi, 10(1), 16-36.

Masrurotun, S., \& Hutabarat, J. (2014). Pengaruh Penambahan Kotorn Ayam, Silase Ikan Rucah dan Tepung Tapioka dalam Media Kultur Terhadap Biomassa , populasi dan Kandungan Nutrisi Cacing Sutera (Tubifex sp.). Journal of Aquaculture Management and Technology, 3(treatment D), 77-85.

Nuraini, Syafruddin Nasution, A. T. dan H. S. (2019). Budidaya Cacing Sutra ( Tubifek sp ) Sebagai Makanan Larva Ikan. Journal of Rural and Urban Community Enpowerment, 1(1), 9-14. 